\title{
GLOBALIZAÇÃO E O DÉFICIT DEMOCRÁTICO DAS INSTITUIÇÕES REPRESENTATIVAS BRASILEIRAS
}

\author{
GLOBALIZATION AND THE DEMOCRATIC DEFICIT OF BRAZILIAN \\ REPRESENTATIVE INSTITUTIONS
}

\author{
Murilo Gaspardo*
}

\begin{abstract}
RESUMO: em decorrência da globalização, o Estado perdeu o monopólio da mediação política. Por exemplo, passou a compartilhar decisões com múltiplos atores, internos e externos, e não é capaz de controlar diversas variáveis que interferem na vida nacional. Isso tem impactos sobre o funcionamento e a legitimidade das instituições representativas. Entretanto, há paradoxos que as acompanham desde seus primórdios e, em Estados semiperiféricos como o Brasil e outros latino-americanos, há questões histórico-culturais, como bloqueios internos e externos à soberania, cultura política patrimonialista, clientelista $\mathrm{e}$ populista, bem como uma sociedade precariamente integrada e com profundas desigualdades, que também explicam os problemas da democracia. Assim, o propósito desta pesquisa consistiu em investigar quais elementos caracterizadores do déficit democrático das instituições representativas brasileiras foram, de fato, causados ou potencializados pela globalização. Com isso, procurou-se superar análises simplificadoras, que atribuem todos os problemas da democracia contemporânea à globalização, ou, então, insistem em restringir o campo de análise aos limites estabelecidos pelo modelo democrático representativo de base territorial, cujo potencial explicativo apresenta limites severos em um contexto de policentrismo político, e em que as instituições representativas se revelam incompatíveis com as exigências de mediação social.
\end{abstract}

PALAVRAS-CHAVE: Democracia representativa. Globalização. Policentrismo político.

ABSTRACT: Due to globalization, the state lost its monopoly on political mediation. For example, it began to share decisions with multiple stakeholders, internal and external, and is not able to control several variables that interfere in national life. This has impacts on the functioning and legitimacy of representative institutions. However, there are paradoxes that accompany them since their beginnings, and semi-peripheral states, like Brazil and other Latin Americans, have some historical-cultural issues such as internal and external sovereignty locks, patrimonial, clientelist, and populist political culture and a society precariously integrated, with deep inequalities, which also explain the problems of democracy. Thus, the purpose of this research was to investigate which characteristic features of the democratic deficit of the Brazilian representative institutions were in fact caused or exacerbated by globalization. Thus, we sought to overcome simplistic analyzes, which attribute all the problems of contemporary democracy to globalization, or else insist on restricting the field of analysis of the limits established by the representative democratic model of territorial base, which presents potential explanatory limited in a context of political

\footnotetext{
* Graduado em Direito pela Universidade de São Paulo (2005), mestre em Direito do Estado pela Universidade de São Paulo (2009) e doutor em Direito do Estado pela Universidade de São Paulo (2013). Atualmente é professor assistente da Universidade Estadual Paulista Júlio de Mesquita Filho-UNESP. Tem experiência na área de Direito, com ênfase em Teoria do Estado. E-mail: murilogaspardo@franca.unesp.br Revista da Faculdade de Direito - UFPR, Curitiba, vol. 60, n. 1, jan./abr. 2015, p. 85-115.
} 
polycentrism, and in that the representative institutions reveal themselves incompatible with the demands of social mediation.

KEYWORDS: Globalization. Political polycentrism. Representative democracy.

\section{INTRODUÇÃO}

A democracia brasileira enfrenta um grande paradoxo: ao mesmo tempo que se consolidou a ideia de que é o único regime político legítimo, cresce a descrença das pessoas em relação às instituições democráticas, o que se manifesta, por exemplo, nos altos índices de abstenção registrados nas últimas eleições ${ }^{1}$ e nas manifestações de junho de 2013 e seus desdobramentos. Compreender adequadamente esse paradoxo e buscar alternativas são tarefas urgentes tanto do campo acadêmico como do político.

A contribuição deste trabalho para tal debate consiste em esclarecer quais elementos caracterizadores do déficit democrático das instituições representativas brasileiras podem ser atribuídos à globalização, seja como causa principal ou fator de potencialização, diagnóstico que, em grande medida, também pode ser aplicado a outros países latino-americanos.

Procura-se, com isto, superar duas vertentes de análises simplificadoras. Por um lado, observa-se que, em decorrência da globalização, o Estado perdeu o monopólio da mediação política. Por exemplo, passou a compartilhar decisões com múltiplos atores, internos e externos, e não é capaz de controlar diversas variáveis que interferem na vida nacional. Isso tem impactos sobre o funcionamento e a legitimidade das instituições representativas. Entretanto, há limites que acompanham a democracia desde seus primórdios e, em Estados semiperiféricos como o Brasil, há questões histórico-culturais que precisam ser especialmente consideradas, como bloqueios internos e externos à soberania, cultura política patrimonialista, clientelista e populista, bem como uma sociedade precariamente integrada e com profundas desigualdades. Assim, não se pode atribuir toda a explicação para os problemas da democracia contemporânea à globalização. Porém, também não é adequado insistir em restringir o campo de análise aos limites estabelecidos pelo modelo democrático representativo de base territorial, cujo potencial explicativo apresenta limites severos em um contexto de policentrismo político, e em que as instituições representativas se revelam incompatíveis com as exigências de mediação social.

\footnotetext{
${ }^{1}$ Não obstante a obrigatoriedade do voto no Brasil, no primeiro turno das eleições de 2014, para Presidente da República, abstenções e votos brancos e nulos somaram vinte e sete por cento dos eleitores (percentual superior ao do segundo colocado na disputa). 
Inicialmente, o desenvolvimento do trabalho compreenderá uma apresentação sobre os limites da democracia representativa existentes desde suas origens e aqueles que são específicos da condição institucional e histórico-cultural brasileira. Em seguida, tratar-se-á dos impactos da globalização e do policentrismo do poder sobre o Estado nacional e o exercício da soberania. Finalmente, cuidar-se-á da relação entre globalização, policentrismo do poder e o déficit democrático das instituições representativas, considerando-se três aspectos: a exclusão social, a crise de motivação e dos programas políticos e a impotência da política.

\section{LIMITES, AMEAÇAS E PARADOXOS DA DEMOCRACIA}

Os problemas enfrentados pela democracia representativa envolvem desde o momento da formação da opinião (dos representados ou dos representantes), passando pela tomada de decisão propriamente dita (eleitoral, no Parlamento ou no Governo), até a execução da decisão.

Antes que o eleitor vote em seu candidato, ou o parlamentar em um projeto de lei, ou o governo escolha a política pública que será adotada, existe uma etapa prévia de formação da opinião daqueles que tomarão suas decisões. Assim, para que decisões sejam tomadas de forma livre e racional, pressupõe-se que os sujeitos estejam bem informados sobre os assuntos em relação aos quais se posicionarão, bem como que tenham condições de influenciar e de serem influenciados pelas opiniões dos outros. Portanto, a democracia depende, fundamentalmente, da formação e da expressão da opinião.

Todavia, observa-se um crescimento da apatia política e do voto pautado por interesses clientelistas frente ao decréscimo do voto orientado por convicções - o que denota que muitas decisões políticas não têm como motivação critérios públicos nem racionais.

Em segundo lugar, existe um fator que, em uma sociedade de massa, é preponderante na formação da opinião: a mídia. Em tese, a mídia pode favorecer a tomada de decisões livres e racionais, pois a ampliação do acesso à informação permite que os cidadãos acompanhem de maneira mais próxima os problemas sociais e o trabalho dos representantes, tendo mais e melhores elementos para realizar seus julgamentos e suas escolhas, da mesma forma que os representantes podem conhecer melhor a opinião dos cidadãos. Porém, o que se nota é a substituição da política real por um espetáculo de ilusões, bastante caro (financiado pelo e conforme os interesses do poder econômico), encenado nos grandes veículos de comunicação de massa, em que os políticos são os atores e os cidadãos meros expectadores, manipulados e 
alienados, como ensina Schwartzenberg (1978, p. 127-329). Ou, como afirma Sartori (2001, p. 50-6), tem-se o fenômeno da "videopolítica" e da "videocracia": se a democracia depende da formação da opinião, e a televisão é uma grande formadora de opinião, logo, "o povo soberano 'opina' sobretudo em virtude da forma com que a televisão o induz a opinar'. Portanto, a televisão condiciona tanto o processo eleitoral como as decisões do Governo, porque os cidadãos, em geral, não apresentam opinião própria sobre os fatos políticos, mas sim uma opinião "heterodirigida", o que acaba por esvaziar "a democracia como governo de opinião. Isso porque a televisão se mostra como porta-voz de uma opinião pública que, na realidade, é apenas eco da própria voz" (SARTORI, 2001, p. 50-6, grifo do autor).

Diante dessas considerações, não seria exagerado concluir que somente nas aparências a vontade expressa pela democracia representativa é formada pelo povo ou pelas correntes majoritárias da sociedade, pois, na verdade, ela é constituída pelo poder dos meios de comunicação de massa mediante a manipulação da opinião, os quais são controlados por oligopólios econômicos e absolutamente livres de controle democrático (BONAVIDES, 2004, p. 29-30).

Com relação aos momentos de tomada de decisões políticas, na expressão de Bobbio (1983, p. 58-63), a democracia enfrenta “paradoxos" e não cumpriu suas "promessas", pois prometeu: (1) eliminar os corpos intermediários entre o indivíduo e o Estado, mas surgiram diversos grupos, como sindicatos e partidos políticos, que exercem o protagonismo da cena política; (2) que os representantes políticos buscariam o interesse nacional, mas representam interesses parciais (por exemplo: bancadas ruralista, religiosa, dos bancos, da indústria de armamento, ambientalista, etc.); (3) derrotar o poder oligárquico, mas a representação política já constitui uma oligarquia (os representantes compõem uma elite); (4) ocupar todos os espaços em que são tomadas decisões vinculantes para a comunidade, mas existem muitos casos de decisões que afetam a todos que são tomadas por métodos não democráticos, como as pertinentes à política econômica; (5) eliminar o poder invisível, mas ele ainda persiste, por exemplo, na tecnocracia.

$\mathrm{Na}$ verdade, essas "promessas da democracia" relacionadas ao processo de decisão política não foram cumpridas porque "o projeto político democrático foi idealizado para uma sociedade muito menos complexa que a de hoje", ou seja: foram surgindo condições sociais que não estavam previstas quando de sua elaboração. Em primeiro lugar, a economia atingiu um nível de complexidade que passou a exigir soluções técnicas e especialistas para lidarem com os problemas de política econômica. Ora, enquanto a democracia exige que todos possam decidir sobre tudo o que se referir aos interesses da coletividade, a complexa sociedade 
industrial (ou pós-industrial) requer que as decisões sejam tomadas pelos tecnocratas. Em segundo lugar, para atender à demanda da crescente intervenção do Estado na economia e na prestação de serviços sociais (decorrente, em parte, da própria universalização do sufrágio), cresceu também a burocracia estatal, mas a lógica hierárquica do poder burocrático contraria a lógica ascendente do poder democrático. Em terceiro lugar, observou-se o que os liberais denominam de "ingovernabilidade da democracia", ou seja, a incapacidade de o governo responder às "demandas que provêm de uma sociedade livre e emancipada", as quais "são sempre mais numerosas, sempre mais urgentes, sempre mais onerosas". Por fim, assinala-se que o ideal democrático pressupunha uma sociedade centrípeta, monista, ou seja, com um único centro de poder para o qual confluiriam todas as decisões que afetassem a coletividade. Porém, na realidade o que se tem é uma sociedade centrífuga e "policêntrica", "poliárquica" ou "pluralista"; portanto, em que convivem vários centros de poder. É por tudo isso que se fala em "paradoxos da democracia". Isso não significa, todavia, que os regimes democráticos tenham se transformado em autocráticos, pois, ainda que imperfeitas, somente as democracias comportam possibilidades de resolução de conflitos e mudanças pacíficas na sociedade (BOBBIO, 2006, p. 36, 46-51).

Para concluir as reflexões sobre os limites da democracia representativa no momento da tomada das decisões política, é preciso tecer algumas considerações sobre a principal regra decisória da democracia: a regra da maioria.

Como não é possível saber, a priori, qual é a melhor decisão que um grupo de pessoas pode tomar a respeito de seus interesses comuns, e o acordo, muitas vezes, revela-se inviável, são necessárias regras para as decisões coletivas, entre as quais a da maioria é a mais importante (BOBBIO, 1983, p. 57). Embora o apoio da maioria seja uma condição de legitimação democrática do poder, como pondera Campilongo (2000, p. 56-8), o processo de decisão política enfrenta novas exigências como rapidez, precisão e eficiência, que nem sempre são atendidas satisfatoriamente por essa regra. Diante disso, conclui-se, acompanhando-se o citado autor (2000, p. 47-54), que "desde que conjugados, a regra (da maioria) e seus limites são indispensáveis à democracia. Porém, incontáveis situações contemporâneas apontam para outras formas, mais legítimas e eficazes, de agregação de interesses". Portanto, o próprio método majoritário está sujeito a questionamentos.

Com relação ao momento da execução da decisão política, a democracia representativa também enfrenta limites como o da "soberania bloqueada" e os impostos pela globalização, dos quais se tratará a seguir, dentre tantos outros. E quando a execução da 
decisão democrática não é eficaz, a formação da opinião e a tomada de decisão também são afetadas, porque passa a haver uma descrença dos cidadãos na democracia.

Por fim, destaca-se uma "ameaça à democracia" que atinge a formação da opinião, o processo decisório e a execução das decisões. Trata-se do "papel cada vez mais decisivo do dinheiro na política", ou seja, o dinheiro se transformou "em um dos fatores essenciais para vencer as eleições e, numa perspectiva mais geral, para obter consensos"2 (VIROLI, 2002, p. $85,98)$.

Portanto, embora todos sejam formal e juridicamente iguais, o poder econômico desiguala a força política de cada sujeito na tomada de decisões que vinculam a coletividade.

Acrescenta-se, ainda, o fato de que, ao mesmo tempo em que se exige que a democracia avance para o campo econômico, constata-se que, frente à complexidade da sociedade contemporânea, o povo se mostra cada vez mais incompetente para decidir sobre essa matéria. Assim, grandes decisões sobre o desenvolvimento econômico nem sequer chegam às instituições representativas, ou apenas são legitimadas por elas, porque de fato foram tomadas em outras instâncias, imunes a qualquer forma de controle democrático (BOBBIO, 1983, p. 61).

Da mesma maneira que o dinheiro representa uma ameaça à formação da opinião e aos processos decisórios democráticos, ele constitui um grande obstáculo para a execução dessas decisões, pois é muito difícil submeter a economia à democracia.

Registra-se, por fim, que a democracia também esbarra nos limites impostos pelo fato de existirem Estados não democráticos, e de que a própria comunidade internacional não é democrática (BOBBIO, 2007, p. 254), bem como em restrições de caráter histórico-cultural.

Em suma, a democracia representativa enfrenta limites antigos à realização de suas promessas, como a deformação da opinião pública pelos meios de comunicação de massa, a inadequação da regra da maioria para resolução de certos tipos de problemas, a grande influência do dinheiro nos processos eleitorais e a imensa dificuldade de se submeter a economia ao controle democrático.

\footnotetext{
${ }^{2}$ Viroli (2002, p. 101) assinala que o "problema do papel preponderante que o dinheiro assumiu na vida política" não é um "fenômeno novo", estando presente, por exemplo, no "regime dos Medici, na Florença do século XV". Todavia, atualmente, "as coisas pioraram porque foi criada uma aliança nova entre poder financeiro e poder ideológico". Bobbio (2002, p. 98) complementa essa ideia, destacando que "os votos, como qualquer outra mercadoria, podem ser comprados. Esta é a razão fundamental pela qual o dinheiro pode corromper a república. Quem tem mais dinheiro tem mais votos".
} 


\section{A CONDIÇÃO INSTITUCIONAL E HISTÓRICO-CULTURAL BRASILEIRA}

Da perspectiva legal-institucional, desde a promulgação da Constituição Federal de 1988 o Brasil preenche todos os requisitos exigidos para a caracterização de uma democracia, combinando o modelo representativo com institutos de democracia semidireta (iniciativa popular, referendo e plebiscito). Há um amplo rol de direitos individuais que asseguram, entre outras liberdades, a de manifestação de pensamento, reunião e associação. Todos os brasileiros maiores de dezesseis anos têm direito ao voto secreto e direto, para a chefia do Poder Executivo e para os órgãos do Legislativo nos diferentes âmbitos da Federação. As eleições são livres e para mandatos por tempo determinado, adotando-se o sistema majoritário para o Executivo e o Senado, e o sistema proporcional para as demais casas legislativas. Todos os que preenchem os requisitos constitucionais (sem quaisquer discriminações) podem se candidatar a mandatos políticos, exclusivamente por meio dos partidos, sendo vigente o pluripartidarismo. Adota-se a forma de Estado federativa e o princípio da separação de poderes, com sistema de governo presidencialista, sendo assegurada a autonomia do Executivo, do Legislativo e do Judiciário.

Nos vinte e seis anos passados desde a nova Constituição, as eleições ocorreram regularmente. Em algumas (poucas) ocasiões foram utilizados os instrumentos de democracia semidireta e as instituições têm funcionado dentro da normalidade jurídica, inclusive em momentos de crise, como o do processo de impeachment do ex-Presidente Fernando Collor de Mello e o do julgamento do caso do mensalão pelo Supremo Tribunal Federal.

Todavia, há algumas características histórico-culturais que acarretam um significativo déficit democrático nas instituições representativas brasileiras, dentre as quais se destacam os bloqueios ao exercício da soberania, de origem externa e interna, a apropriação do Estado por interesses privados, o populismo, a histórica ausência do Estado perante graves problemas sociais, a desigualdade e a exclusão social, e a baixa integração social.

A soberania brasileira, tanto em seu aspecto externo quanto interno, sempre apresentou a condição de uma "soberania bloqueada" (STUCHI, 2007, p. 177). Com relação ao bloqueio externo à soberania nacional, embora seja verdade que, na última década, o Brasil tenha atingido uma expressão maior no contexto internacional, tanto em termos políticos como econômicos, os indicadores sociais (com destaque para o ainda precário padrão educacional e a questão da violência) e econômicos (como a preponderância de produtos primários em suas exportações), sua dependência tecnológica e limitado poder militar não permitem afirmar que tenha deixado a condição de Estado em desenvolvimento ou 
semiperiférico. Portanto, o Brasil continua a não pertencer ao centro da política mundial, e a ter sua soberania bloqueada ou restringida pela posição que ocupa em relação a outros Estados onde estão concentradas as decisões econômicas, o poder e a riqueza ${ }^{3}$. Entretanto, o bloqueio à soberania brasileira não decorre apenas de fatores externos, mas também internos: poderosos atores econômicos nacionais limitam o exercício da soberania estatal. Ou seja, esse poder submete o Estado, que deveria estar sob o controle da soberania popular, fazendo com que recursos públicos sejam empregados para atender a interesses privados.

Isso fica evidenciado nas ações governamentais que favorecem com mais obras, subvenções e todo tipo de investimentos e serviços públicos os setores da sociedade mais articulados, economicamente poderosos e com maior capacidade de pressão, "independentemente de quaisquer critérios de necessidade ou de relevância social" (FARIA, 2010, p. 127-8).

A apropriação do Estado brasileiro também ocorre, desde os tempos da colonização, pelos ocupantes das funções públicas de comando. Trata-se de uma herança do Estado português que resistiu a diferentes mudanças institucionais: passou da Colônia ao Império, do Império à República Velha, da República Velha à Era Vargas e, adaptando-se a cada período, permanece até os dias de hoje (COMPARATO, 2007, p. 11-2).

Faoro (1979, p. 733), ao estudar esse fenômeno nos anos cinquenta do século XX, valendo-se da teoria weberiana, denominou-o de "patrimonialismo", explicando que se tratava da condução dos negócios do Estado como se fossem negócios privados da "comunidade política".

A comunidade política, de que tratava Faoro (1979, 737-8), constituía-se em agrupamento social, nem sempre articulado ou homogêneo, acima da sociedade, governando “em nome próprio, num círculo impermeável de comando", apossando-se do aparelho estatal, e representando somente os próprios interesses. Ainda que seus componentes mudassem ao longo do tempo, logo que passavam a integrá-la eram impregnados por seus valores. Assim, o "estamento político" não representava um "governo da soberania popular, ajustando-se, no máximo, à autocracia com técnicas democráticas".

De forma correspondente ao patrimonialismo praticado pelo "estamento político", Faoro (1979, p. 748) explica que

\footnotetext{
${ }^{3}$ Para aprofundamento desta questão, cf. BERCOVICI, 2009, p. 275, NOGUEIRA, 2008, p. 14, STUCHI, 2007, p. 244. 
o comportamento do povo oscila entre o parasitismo, a mobilização das passeatas sem participação política, a nacionalização do poder, mais preocupado com os novos senhores, filhos do dinheiro e da subversão, do que com os comandantes do alto, paternais e, como o bom príncipe, dispensários de justiça e proteção. A lei, retórica e elegante, não o interessa. A eleição, mesmo formalmente livre, lhe reserva a escolha entre opções que ele não formulou.

Portanto, patrimonialismo e clientelismo caminhavam juntos na apropriação do Estado por interesses privados, e transformavam os procedimentos democráticos em formalidades desprovidas da essência democrática.

A resistência do patrimonialismo (e do clientelismo) às mudanças sociais e políticas, de que tratava Faoro ao analisar a história, também se revelou como previsão, pois, não obstante o tempo passado desde a publicação de sua obra, em sua essência, o fenômeno persiste no Brasil, resistindo, inclusive, ao último processo de redemocratização e à Constituição Federal de 1988. Temos, pois, na expressão de Benevides (2009, p. 729), uma "república privatista" como uma das "patologias históricas" da sociedade brasileira, ainda organizada oligarquicamente.

Isso porque, não obstante a nova estrutura legal-institucional, persistem velhos hábitos, a mesma cultura política. Inclusive, "egressos da antiga ordem foram gradualmente ocupando os espaços políticos e impondo a sua peculiar forma de fazer política aos que lutaram contra o autoritarismo". A consequência disso é a transformação da democracia "em uma farsa", com a participação popular se reduzindo a uma formalidade, em processos eleitorais com debates esvaziados de conteúdo e decrescente interesse da população (VILLA, 2012, p. A3).

Portanto, como Nogueira (2008, p. 15-16) conclui,

a democracia conquistada pelas lutas contra a ditadura não chegou a se institucionalizar plenamente nem a se converter em cultura, e isso tanto porque se expandiu em termos prevalecentemente eleitorais sem um correspondente adensamento ético-político, quanto porque cresceu por fora do Estado, sem envolvêlo e "responsabilizá-1o"4.

\footnotetext{
${ }^{4}$ Um exemplo que demonstra com clareza o fato de que a democracia não se enraizou na cultura política brasileira é o fenômeno que Nobre (2011, p. I. 4-5) denomina de "peemedebismo". O autor explica que não se trata de uma cultura restrita ao PMDB, mas se vale desse nome porque foi esse "partido que primeiro, ainda nos anos 1980, a moldou e consolidou". Ela funciona segundo uma lógica em que se aceita o ingresso no partido de qualquer grupo de interesse, o qual, quando se organiza e se fortalece, passa a ter uma participação garantida nos fundos públicos e o direito de vetar decisões referentes a questões que lhes interesse. Para que funcione, o pressuposto é que "o partido esteja permanentemente no poder, seja qual for o governo", e assim funcionou recentemente, tanto com o PSDB, como com o PT. Desta maneira, o partido do Presidente da República desempenha a função de "síndico do condomínio peemedebista". Não interessa ao PMDB ocupar a Presidência, mas apenas se valer de sua participação no poder para atender aos interesses dos grupos que o compõe.

Revista da Faculdade de Direito - UFPR, Curitiba, vol. 60, n. 1, jan./abr. 2015, p. 85-115.
} 
No que se refere ao clientelismo, ele não tem mais sua principal expressão nas relações de parentesco e amizade, mas sim na corrupção, a qual se manifesta em todas as esferas governamentais, por exemplo, em todo tipo de contratos e licitações, de obras públicas à propaganda oficial, por meio do favorecimento de determinados agentes econômicos, em vez de se aplicar uma regra que permita a igual participação de todos os possíveis interessados (LAMONIER, 2010, p. 94-5).

Além da apropriação do Estado por interesses privados, outro fenômeno que compromete o bom funcionamento das instituições democráticas no Brasil é o populismo. Trata-se de uma forma de poder baseada na relação direta e emocional do líder político com as massas, valendo-se de um discurso demagógico e aproveitando-se da pobreza material e cultural que permite esse tipo de manipulação. O governante populista se recusa a se submeter aos critérios públicos, às regras e aos procedimentos legalmente estabelecidos, dirigindo os negócios públicos conforme sua vontade, já que entende que a legitimidade de seu poder decorre de seu carisma, da empatia com o povo, e não das instituições, o que se revela incompatível com o Estado democrático (LAMONIER, 2010, p. 86-90).

Por fim, acentua-se que a sociedade brasileira, em virtude da exclusão e das desigualdades sociais ${ }^{5}$, da não concretização de direitos por meio dos procedimentos constitucionais, e da convivência de sujeitos privilegiados com subintegrados (NEVES, 2008, p. 250-4), caracteriza-se por profundas divisões que criam grande dificuldade para a formulação de uma noção concreta de interesse público, ou de interesses comuns, o que é essencial para a prática democrática (FARIA, 2003, p. 80-6). Acrescenta-se a isso a histórica ausência do Estado brasileiro perante grandes desafios sociais como a educação e a violência, e temos a configuração do quadro sociocultural pátrio.

Valendo-se de outros instrumentais analíticos, Neves (2008, p. 236-47) descreve de maneira bastante interessante o que significa a condição brasileira de Estado semiperiférico. Primeiramente, aponta que, ao contrário da idealização da teoria sistêmica de Luhmann, não ocorreu suficientemente a diferenciação funcional entre os sistemas sociais, como o econômico e o político. É notória a intromissão do sistema político no econômico, desequilibrando a competição no mercado mediante favorecimentos, seja por meio de normas

\footnotetext{
${ }^{5}$ Com relação à questão da desigualdade no Brasil, salienta-se que, apesar dos avanços significativos ocorridos nos últimos tempos (em menos de quinze anos, houve uma "redução da pobreza absoluta de $34 \%$ e da extrema em 50\%"), "o problema é que se parte de tão baixo - o critério da pobreza absoluta é menos da metade do salário mínimo e o da extrema, menos de um quarto - que as conquistas são insuficientes. O mesmo ocorre com a desigualdade, com declínio médio anual de $1,2 \%$, o que coloca o Brasil entre os 16 países de maior redução. Nesse ritmo, no entanto, levaremos mais de 25 anos para chegar ao índice dos americanos" (RICUPERO, 2011, p. M3).
} 
ou de créditos, de determinadas empresas ou segmentos, em prejuízo dos demais, por razões que variam da ideologia à corrupção, o que contribui para a ineficiência do funcionamento do sistema econômico. Por outro lado, o sistema econômico também interfere no político; por exemplo, influenciando, ou até determinando, o resultado de eleições e o processo legislativo, de maneira que o desempenho das funções do sistema político fica bloqueado. Em segundo lugar, o autor destaca que nos países periféricos não ocorreu a formação de "uma esfera pública pluralista fundada na generalização institucional da cidadania", tal como pressupõe o modelo democrático de Habermas (2001). Isso ocorre porque, embora todos sejam formalmente iguais, a prática jurídica revela a permanência de privilegiados, ou seja, o direito não é igual para todos. Além disso, predomina a "exclusão de grandes parcelas da população" do acesso aos mais básicos direitos humanos, os quais, embora sejam constitucional e legalmente garantidos, não são concretizados. $\mathrm{O}$ acesso aos direitos não se dá segundo procedimentos constitucionalmente previstos, mas sim conforme outros critérios, tais como relações sociais ou poder econômico, o que leva a um processo de "privatização do Estado". Ora, sem concretização de direitos, predomina a lógica dos favores e do clientelismo. Em decorrência desse processo, esses segmentos da população também são excluídos da participação efetiva do processo político (embora, mais uma vez, formalmente todos possam participar de forma igual).

O que se observa, pois, seja em virtude da dependência externa, do domínio do poder econômico ou do "estamento político", é que o Estado brasileiro nunca chegou a constituir (nem no passado, nem no presente) uma verdadeira esfera pública ${ }^{6}$, ou seja, o lócus da mediação política, pois, sempre foi (e em grande medida continua a ser) dominado por interesses privados; em outras palavras, não realiza a mediação dos interesses da coletividade (com igual consideração de todos os interessados), mas sim daqueles que, direta ou indiretamente, controlam o aparelho estatal: classe política, burocracia/tecnocracia, poder econômico, poderes corporativos e meios de comunicação de massa. Predomina, pois, no Brasil, a confusão entre o público e o privado $^{7}$, a cultura do favorecimento de amigos, da formação de clientelas políticas e da naturalização da corrupção.

Essas constatações implicam, primeiramente, que não se pode depositar toda a crença na transformação da realidade democrática brasileira em modelos institucionais. Isso não significa que as instituições não cumprem um papel importante; pelo contrário, são essenciais

\footnotetext{
${ }^{6}$ Não se emprega o termo, aqui, no sentido utilizado por Habermas (2001).

${ }^{7}$ Para uma análise aprofundada deste problema, cf. HOLLANDA, 1971, p. 101-12. Revista da Faculdade de Direito - UFPR, Curitiba, vol. 60, n. 1, jan./abr. 2015, p. 85-115.
} 
para a prática democrática. Todavia, é fundamental que sejam compatíveis com a realidade histórico-cultural em que estão inseridas, inclusive para realizar seu eventual potencial transformador. Portanto, a engenharia institucional não deve se basear em idealizações, mas sim no reconhecimento de que a cultura republicana e democrática ainda não está consolidada no Brasil.

Em segundo lugar, as discussões sobre a democracia no Brasil não devem caminhar no sentido de uma proposta de retorno ao passado, ou seja, por uma argumentação segundo a qual a globalização e o policentrismo político representam uma ameaça à soberania popular que existia antes de tais fenômenos, pois o povo nunca foi de fato soberano: em nenhum momento da história brasileira o funcionamento da democracia se aproximou dos ideais democráticos ou atendeu satisfatoriamente aos requisitos de medição da qualidade da democracia. Tanto fatores internos, como muitos dos externos que bloqueiam a soberania e a democracia brasileiras são anteriores ao atual processo de globalização. Assim, é preciso ter a clareza sobre quais são as causas realmente novas (e relacionadas com a globalização e o policentrismo do poder) do déficit democrático das instituições representativas brasileiras.

\section{O ESTADO NACIONAL DIANTE DA GLOBALIZAÇÃO E DO POLICENTRISMO DO PODER}

O Estado nacional sempre desempenhou, e continua a desempenhar, um papel fundamental na mediação social. No campo econômico, regras que permitem o funcionamento do mercado (como o direito de propriedade e a disciplina dos contratos) são definidas legalmente e garantidas pelo Estado (por exemplo, pela atuação do Poder Judiciário e da polícia). Por meio dos diferentes instrumentos de política econômica e regulatórios, o Estado procura (ou deveria procurar) sanar falhas do mercado e direcioná-lo para atender aos interesses nacionais (como distribuição de renda e proteção ao meio ambiente), os quais, ao menos em tese, são democraticamente definidos pelas instituições representativas. Além disso, o Estado atua na mediação dos conflitos pela distribuição de riquezas. $\mathrm{Na}$ área social (em sentido estrito), o Estado, apesar de suas deficiências, presta serviços importantes de saúde, educação, segurança, etc., os quais são essenciais para a garantia de direitos fundamentais, a redução de conflitos e a promoção da coesão social.

É verdade, como já exposto, que, no Brasil, nunca chegou a se consolidar plenamente o modelo de Estado Social, e sua soberania sempre foi bloqueada. Todavia, com o fenômeno da globalização, a capacidade de o Estado, por meio de mecanismos políticos e jurídicos, 
definir autonomamente e concretizar a política econômica, regular atividades econômicas estratégicas e mediar conflitos distributivos foi bastante comprometida ${ }^{8}$ (FARIA, 2010, p. 292-3). Da mesma maneira, em virtude das reformas neoliberais e de limites orçamentários (além, evidentemente, dos enraizados problemas da ineficiência e da corrupção), o Estado não consegue atender satisfatoriamente as demandas que lhe são apresentadas, sobretudo para compensar as consequências sociais da competição global (FARIA, 2010, p. 141-2). Há outro conjunto de problemas que, pela natureza que assumiram com o desenvolvimento da globalização (como o tráfico de drogas e a criminalidade internacional, a poluição e o terrorismo), os Estados não conseguem controlar adequadamente (HÖFFE, 2005, p. 194-5). Por outro lado, decisões políticas tomadas no âmbito nacional, por exemplo, nos campos econômico, ambiental, sanitário e de segurança, também afetam outros Estados ${ }^{9}$ (HELD; MCGREW, 2007, p. 6-7).

Por exemplo, a interdependência global dos mercados de capitais limitou as opções do Estado e a eficácia de suas decisões com relação às políticas monetárias (LEWANDOWSKI, 2004, p. 70-1), fiscal e de crédito, pois ele não consegue controlar o fluxo de capitais. São as grandes instituições financeiras e demais corporações transnacionais que definem em que, onde, quanto e quando se investirá. Essa capacidade dos atores do mercado de escaparem à regulação ou se sobreporem ao Estado ocorre, por um lado, devido à combinação de um processo decisório centralizado com a fragmentação de suas atividades, constituindo-se em redes espalhadas por todo o mundo, com grande facilidade para realocar investimentos, tecnologias e demais fatores de produção ${ }^{10}$. Por outro lado, isso se deve à restrição da ação do Estado aos limites de seu território. Ora, se parte significativa dos problemas econômicos existentes dentro das fronteiras nacionais (como o desemprego, a pobreza e a concentração de renda) é, em grande medida, resultante de decisões de agentes externos e da conjuntura econômica internacional, os Estados não se mostram capazes de enfrentá-los adequadamente.

Portanto, uma das faces do impacto da globalização sobre os Estados nacionais é a existência de fenômenos que afetam significativamente suas economias e a vida de seus

\footnotetext{
${ }^{8}$ Nesse sentido, Beck (1999, p. 18) explica que a sociedade mundial, constituída no processo de globalização em suas múltiplas dimensões, "relativiza e interfere na atuação do Estado nacional, pois uma imensa variedade de lugares conectados entre si cruza suas fronteiras territoriais, estabelecendo novos círculos sociais, redes de comunicação, relações de mercado e formas de convivência".

${ }^{9}$ Esta ideia segundo a qual tudo o que se passa no mundo, de certa forma, interfere na vida do "homem de tipo médio", já foi enunciada por Ortega y Gasset (2002, p. 39), em escritos originalmente publicados a partir de 1926. Entretanto, não se pode negar que o processo contemporâneo de globalização apresenta especificidades que o distinguem não somente em grau, mas de forma substancial.

${ }^{10}$ Para aprofundamento deste tema, cf. FARIA, 2002, p. 64-108; 2011, p. 2-3; IANNI, 2000, p. 66. Revista da Faculdade de Direito - UFPR, Curitiba, vol. 60, n. 1, jan./abr. 2015, p. 85-115.
} 
cidadãos, em relação aos quais não têm controle. Isso ocorre, por um lado, porque tais fenômenos se processam globalmente e, por outro, porque os Estados tiveram sua capacidade de atuação enfraquecida, inclusive na perspectiva orçamentária. Outra face desse problema é a divisão do poder político do Estado, no sentido de tomada de decisões sobre o que é comum a todos, com outros poderosos atores nacionais e internacionais ${ }^{11}$, os quais exercem seu poder por meio de estruturas horizontais e em forma de redes.

Dentre esses atores, destacam-se as corporações transnacionais. Evidentemente, não são todas as empresas que atuam mundialmente - os mercados internos continuam a representar a maior parte do PIB na maioria dos países, e o setor governamental ainda detém parcela significativa dos empregos e do consumo dos países. Porém, as empresas dos setores mais estratégicos de todas as economias nacionais estão fortemente conectadas com o mercado global de bens e serviços, o qual é dominado por corporações transnacionais que constituem "redes transnacionais de produção". Consequentemente, "o dinamismo dos mercados internos depende, em última análise, da capacidade das empresas do país e das redes de empresas para competir globalmente" (CASTELLS, 2009, p. 156-7, 163). Como o desempenho das economias nacionais está atrelado ao mercado global que é dominado pelas corporações transnacionais, essas companhias acabam dividindo com o Estado o poder de definir os rumos do desenvolvimento nacional. Registra-se, por outro lado, como observa Dowbor (2001, p. 51) que, embora as empresas transnacionais sejam apresentadas como “apátridas', sem bases nacionais”, o que é parcialmente verdadeiro, na medida em que "seguem dinâmicas internas e não servem propriamente nenhum interesse nacional", também é incontestável o fato de que "nenhuma destas firmas deixará de aproveitar a força política que as suas raízes nacionais lhe conferem, mobilizando, assim, no apoio às suas atividades, os seus congressos, seus executivos, e se necessário seus exércitos"12.

Além das corporações transnacionais, os Estados dividem sua função de mediação política com organizações internacionais (como o Fundo Monetário Internacional e a Organização Mundial do Comércio ${ }^{13}$ ), blocos regionais (como a União Europeia e o Mercosul) e organizações não-governamentais, inclusive de caráter transnacional.

\footnotetext{
${ }^{11}$ Cf. BECK, 1999, p. 18.

${ }^{12}$ A propósito, cf. a análise de Arendt (1989, p. 147 et seq.) sobre o desenvolvimento do Imperialismo no final do Século XIX.

${ }^{13}$ Embora a adesão de um Estado a uma organização internacional seja voluntária e, em tese, ele tenha poder para participar de suas decisões, muitas vezes, na prática, é impossível não aderir a elas, e seu controle de fato cabe a um pequeno grupo de países econômica e politicamente mais poderosos (CASSESE, 2000, p. 18-9).

Revista da Faculdade de Direito - UFPR, Curitiba, vol. 60, n. 1, jan./abr. 2015, p. 85-115.
} 
Dessa multiplicidade de atores dividindo a arena política com os Estados nacionais resulta uma terceira vertente do impacto da globalização sobre eles, a qual se manifesta no campo do direito: a substituição do monismo pelo pluralismo jurídico (ou normativo), o processo de homogeneização do direito e a limitação do âmbito da jurisdição estatal.

O pluralismo jurídico pode ser definido como a "existência de distintas ordens jurídicas autônomas num mesmo espaço geopolítico, intercruzando-se e interpenetrando-se de modo constante" (FARIA, 2002, p. 15). É exatamente isso que ocorre no presente momento: as instituições legislativas estatais passam a concorrer (ou até ceder seu lugar em determinados campos do direito) para "novas fontes de produção normativa" supranacionais, privadas e comunitárias $^{14}$ (FARIA, 2011, p. 8). Diante disso, os processos conhecidos como "desregulamentação e deslegalização" na verdade não representam uma redução da normatização e da mediação jurídica da sociedade, mas sim do direito positivo estatal e das instituições estatais, os quais cedem espaço para uma normatividade difusa produzida por diferentes atores econômicos e sociais, bem como para a "auto-regulação e auto-composição de conflitos" (FARIA, 2008, p. 61).

Já a tendência à homogeneização do direito significa que a produção normativa e os diversos regimes legais (nacionais e transnacionais) passam a ser orientados pelos mesmos valores e conceitos, que não são os de justiça ou da busca do bem comum e dos interesses nacionais, mas aqueles determinados pelos interesses dos detentores do poder econômico (sobretudo das economias centrais) em viabilizar soluções técnicas que facilitem o fluxo econômico e a ampliação de sua riqueza (como a proteção da propriedade intelectual, a segurança jurídica e a liberalização dos mercados), sob a coordenação e fiscalização de órgãos como o Fundo Monetário Internacional, o Banco Mundial e a Organização Mundial do Comércio (FARIA, 2011, p. 10; 2008, p. 39; 2002, p. 84-5).

Por fim, observa-se uma redução do âmbito da jurisdição estatal. Isso ocorre porque crescem os problemas que afetam os cidadãos de cada Estado com dimensão transnacional, enquanto que as normas e os tribunais que devem aplicá-las podem atuar somente nos limites do território nacional. Assim, menos questões relevantes para a população de cada Estado dependem exclusivamente da jurisdição estatal (FARIA, 2002, p. 70).

\footnotetext{
${ }^{14}$ Surgem, em especial, duas formas de normatividade: a "nova" Lex Mercatoria e o "Direito da Produção" (FARIA, 2011, p. 11-3). 
A quarta manifestação dos impactos da globalização sobre os Estados nacionais pode ser observada na crescente incompatibilidade entre o tempo do Estado nacional e o de outros processos sociais.

O tempo do Estado é o tempo da política e da burocracia: eleições, processos legislativos e judiciais, formação de consensos sociais e da memória histórica nacional, formulação e execução das políticas públicas, etc. Todavia, outras temporalidades apresentam importância cada vez maior, desde a instantaneidade do ciberespaço e dos mercados financeiros, até o "tempo glacial da degradação ecológica, da questão indígena ou da biodiversidade", o qual é imensamente mais lento do que o tempo do Estado nacional. Tratase, pois, de temporalidades muito distintas (BOAVENTURA DE SOUSA SANTOS, 1999, p. 93-4).

Isso tem consequências importantes para o Estado e para a democracia. Primeiramente, os atores que conseguem se adaptar à velocidade do tempo que domina as relações na contemporaneidade, especialmente à instantaneidade, tendem a ter maior poder. Por exemplo, "o capital pode viajar rápido e leve, e sua leveza e mobilidade se tornam as fontes mais importantes de incerteza para todo o resto. Essa é hoje a principal base da dominação e o principal fator das divisões sociais". O mesmo não se pode dizer com relação às decisões e à mobilização dos recursos políticos. Além disso, a ideia de "longo prazo" perdeu importância, a modernidade "fluida" a substituiu pelo "curto prazo" e "fez da instantaneidade seu ideal último"15 (BAUMAN, 2001, p. 139-41, 145-7).

Há, portanto, quatro maneiras fundamentais de incidência da globalização nos Estados nacionais: (1) fenômenos que afetam significativamente suas economias e a vida de seus cidadãos, em relação aos quais não têm controle; (2) pluralidade de atores com os quais passou a dividir a cena política; (3) pluralismo jurídico, homogeneização do direito e redução do âmbito da jurisdição estatal; e (4) incompatibilidade entre o tempo do Estado e o tempo de outros processos sociais com importância crescente. Tudo isso resulta em um questionamento sobre a permanência da ideia de soberania como nota distintiva dos Estados nacionais. Não há consenso, todavia, quanto à dimensão do problema.

Zolo (2006, p. 79-82), por exemplo, entende que "o declínio da soberania dos Estados nacionais" aparenta ser um processo irreversível, de forma que estaria “definitivamente em crise o sistema westfaliano dos Estados soberanos". Para fundamentar

\footnotetext{
${ }^{15}$ De acordo com Boaventura de Sousa Santos (1999, p. 109), a resposta para esse problema pode vir ou da aceleração do tempo da política ou da desaceleração do tempo da economia, de maneira que a situação descrita exige a "reconstrução ou reinvenção de um espaço-tempo que favoreça e promova a deliberação democrática".

Revista da Faculdade de Direito - UFPR, Curitiba, vol. 60, n. 1, jan./abr. 2015, p. 85-115.
} 
sua posição, o autor afirma que os Estados não estão "em condições de enfrentar problemas de escala global". Diante disso, como já mencionado, passam a compartilhar seu poder (inclusive o de estabelecer o direito) com outros poderosos atores na "arena internacional".

Já Lewandowski (2004, p. 254) tem uma posição um pouco diferente. O autor reconhece que a globalização apresenta grande impacto na soberania, pois, pela primeira vez desde a consolidação do Estado moderno, ele "não consegue mais controlar de forma satisfatória a repercussão doméstica das variáveis econômicas geradas externamente". Todavia, Lewandowski (2004, p. 300) entende que não há elementos que indicam o fim do Estado ou da soberania em um futuro próximo. Isso porque, em primeiro lugar, "embora os Estados possam ter eventualmente a autonomia cerceada em alguns aspectos, a sua soberania, ao menos no que ela tem de essencial, não se vê afetada". Além disso, a soberania ilimitada nunca existiu, e "muito menos tem lugar nos dias atuais, sobretudo porque as transformações históricas pelas quais os Estados passaram fizeram com que ela acabasse ficando mais flexível do que a noção legada pela tradição".

Entende-se que o Estado nacional continua a ser um ator político fundamental e decisivo (por seu poder militar, econômico, tecnológico, cultural, etc.), existindo atribuições que lhe são próprias e que não podem ser transferidas para as esferas regionais, global ou mesmo locais ${ }^{16}$. Todavia, o Estado não é capaz de resolver uma série de problemas que atingem significativamente a vida de seus cidadãos, devido ao seu caráter transnacional, e deixa de ser o único centro político decisório: a decisão última não pertence mais a ele, nem a qualquer outro ator isoladamente, seja nacional ou internacional. Decisões que anteriormente eram exclusivas do Estado passam a ser condicionadas e compartilhadas (FARIA, 2011, p. 67). Consequentemente, os Estados são obrigados a negociar e firmar compromissos com diversos sujeitos que apresentam certa autonomia em relação a ele e que operam conforme procedimentos decisórios próprios (AMARAL, 2008, p. 39-41).

Em um cenário como esse, se não é possível afirmar que se está diante do colapso da soberania, é correto o entendimento de que se está a passar por uma relativização (CASSESSE, 2003) e uma reconfiguração (HELD, 2006, p. 304): embora se mostre formalmente intacta, ela se encontra substancialmente comprometida, pois, na prática, muitos Estados não conseguem estabelecer autonomamente seus objetivos nacionais e concretizá-los (FARIA, 2011, p. 3), e as instituições fundadas no Estado nacional não conseguem responder satisfatoriamente a uma série de problemas, simplesmente porque suas causas e dinâmicas

\footnotetext{
${ }^{16}$ Neste sentido, cf., por exemplo, HÖFFE, 2005, p. 6-7. Revista da Faculdade de Direito - UFPR, Curitiba, vol. 60, n. 1, jan./abr. 2015, p. 85-115.
} 
extrapolam os limites de suas jurisdições. Desta maneira, como o Estado não detém a exclusividade da tomada e concretização das decisões que afetam a coletividade e como o poder se encontra desconcentrado, descentralizado e fragmentado entre vários atores de diferentes esferas de atuação, as decisões ocorrem a partir da formação de redes globais complexas, havendo uma radical reconfiguração do poder político, ou seja, está-se diante do policentrismo do poder (FARIA, 2002, p. 7, 14-5, 23-4). Consequentemente, a sede da prática política e da democracia não está mais circunscrita ao Estado nacional, devendo ser compreendida também em termos de governança local, regional e global.

\section{GLOBALIZAÇÃO, POLICENTRISMO DO PODER E DÉFICIT DEMOCRÁTICO DAS INSTITUIÇÕES REPRESENTATIVAS}

Nas seções 1 e 2, foram apresentados fatores que demonstram que as instituições representativas, ao longo da história, enfrentaram problemas desde o momento da formação da opinião, passando pela tomada de decisão, até sua execução. Confrontando tais considerações com o que foi exposto na seção 3, pode-se observar que a totalidade desses problemas permaneceu e alguns se agravaram.

Dentre os problemas que se agravaram, destacar-se-á, na primeira parte deste item, a exclusão social, devido às dimensões que ganhou e à maneira como compromete a legitimidade e a efetividade da democracia. Em seguida, tratar-se-á das crises de motivação para a participação política e dos programas partidários, as quais estão diretamente relacionadas com a globalização e o policentrismo do poder, e comprometem severamente a democracia representativa nos momentos de formação da opinião e de tomada de decisão política. Por fim, cuidar-se-á de um fenômeno que afeta o momento da execução da decisão: a crise de impotência da política, que também decorre dos impactos da globalização sobre o Estado nacional e é causadora de significativo déficit democrático nas instituições representativas.

\subsection{DÉFICIT DEMOCRÁTICO DAS INSTITUIÇÕES REPRESENTATIVAS E A EXCLUSÃO SOCIAL}

Além de suas consequências socioeconômicas, a exclusão social e a miséria, aprofundadas pela globalização, apresentam importante repercussão política e são causadoras de déficit democrático das instituições representativas. 
Em primeiro lugar, a miséria provoca o enfraquecimento do "sentimento de valor próprio" e a exclusão sociocultural dos cidadãos que vivem nessas condições, favorecendo a apatia política - a qual interessa aos atores dominantes da sociedade, pois contribui com a manutenção do status quo, além de deslegitimar os governos, constituindo uma ameaça à própria democracia, pois esvazia o seu conteúdo (MÜLLER, 2005, p. 2-3, 6-7). Quem vive à margem da sociedade, sem direitos sociais básicos e a dignidade respeitados, não acredita que de fato tem poder para interferir no processo político e não se sente igual aos sujeitos economicamente favorecidos, de maneira que acabam por se render ao clientelismo ou simplesmente se conformam com sua condição de subordinados e excluídos. Da mesma maneira, aqueles que são socioculturalmente excluídos enfrentam grandes limitações para formarem livremente suas opiniões e influenciarem a dos demais sujeitos.

Em segundo lugar, "a insegurança sobre como ganhar a vida", decorrente do desemprego (ou de sua constante ameaça) e do subemprego, somada à "ausência de um agente confiável capaz de tornar essa situação menos insegura ou que sirva pelo menos de canal para as reivindicações de uma segurança maior" (que se explica pela crise do Estado Social) comprometem a independência de participação política e as possibilidades de engajamento em projetos coletivos e transformadores (BAUMAN, 2000, p. 28). Ou seja, quem não tem segurança sobre as condições de sobrevivência próprias e de sua família acaba sendo tomado por essas preocupações e não se envolve em ações coletivas.

Por essas razões, Bauman (2000, p. 179-82) afirma que "tirar os pobres da miséria não é apenas uma questão de caridade, consciência e dever moral, mas condição indispensável (embora apenas preliminar) para reconstruir uma república de cidadãos livres a partir do deserto que é o mercado global”, pois a ordem global de certa forma depende da situação de medo e incerteza que essas pessoas vivem para se perpetuar. Ou seja, a questão da pobreza e da miséria não pode ser analisada somente a partir das perspectivas da moral, da caridade, e da insegurança ou violência que podem resultar, mas também de suas consequências políticas. Quem está nessa condição tem sua liberdade política efetiva extremamente reduzida e quem não está teme um dia estar, então prefere não se arriscar em um projeto para mudar a ordem vigente. O elemento fundamental dessa condição é o desemprego estrutural: "o meio de vida, essa rocha em que se devem assentar todos os projetos de vida para ser viáveis, fazer sentido e reunir energia necessária para se realizarem (ou, pelo menos, tentarem isso), tornou-se inseguro, errático, inconfiável". O "meio de vida", além de assegurar o "sustento diário", é responsável por "dar segurança existencial, sem a qual nem a liberdade nem a vontade de auto-afirmação são concebíveis e que é o ponto de partida para a autonomia”. 


\subsection{DÉFICIT DEMOCRÁTICO DAS INSTITUIÇÕES REPRESENTATIVAS E A CRISE DE MOTIVAÇÃO E DE PROGRAMAS POLÍTICOS}

Juntamente com a perda de poder decisório do Estado, a globalização (não só por força de sua dimensão econômica, mas também da ideológica), implica a redução das alternativas político-programáticas, pois os partidos com vocação para ocupar espaços no governo tendem a um alinhamento ao centro, perdem sua ideologia, enquadrando-se dentro dos limites das alternativas "supostamente viáveis". Com isso, a democracia perde seu conteúdo substantivo: por um lado, como se discutirá no próximo item, a ação política se revela impotente; por outro, não há programas políticos significativamente diferenciados em disputa. Esses dois fatores provocam uma crise de motivação para a participação política, a qual é percebida como algo inútil. Afinal, porque os cidadãos se interessariam por participar das instituições representativas se os centros em que efetivamente são tomadas as decisões que lhes afetam estão distantes e não há verdadeiras escolhas a serem feitas ${ }^{17}$ ?

Encontramos em Bauman (2000, p. 78-80) uma importante explicação para a redução das alternativas político-programáticas. De acordo com o autor, as escolhas dos indivíduos podem sofrer duas formas de restrição: a "agenda de opções", por meio da qual se diferenciam as "opções teoricamente possíveis" das que são "proibidas e puníveis", conforme definido pela legislação, e "código de escolhas", ou seja, o conjunto de "regras que indicam com base em que se deve preferir uma coisa a outras e quando a escolha é adequada ou não", cujo principal instrumento é a educação. Tanto a definição da agenda pela legislação, como a dos códigos de escolha pela educação, tiveram, ao longo da modernidade, uma participação protagonista da política. Todavia, “as instituições políticas vigentes vivem hoje um processo de abandono ou diminuição do seu papel de criadoras de códigos e agenda". Isso não significa necessariamente que a liberdade individual esteja sendo ampliada, mas sim que "a função de estabelecer código e agenda está sendo decididamente transferida das instituições políticas (isto é, eleitas e em princípio controladas) para outras forças”. Desta forma,

o recuo ou autolimitação do Estado tem como efeito mais destacado uma maior exposição dos optantes tanto ao impacto coercitivo (agendador) como doutrinador (codificador) de forças essencialmente não políticas, primordialmente aquelas associadas aos mercados financeiros e de consumo (BAUMAN, 2000, p. 80).

\footnotetext{
${ }^{17}$ Esta questão é discutida, por exemplo, por Nogueira (2008, p. 10) e Mouffe (2006, p. 3). Um fenômeno diretamente relacionado com esta crise de legitimidade e efetividade das instituições participativas é a denominada judicialização da política, ou seja, procura-se no Judiciário uma alternativa para os problemas do circuito Governo-Parlamento. Entretanto, este tipo de atuação do Judiciário também apresenta uma séria de riscos e limites materiais, organizacionais, operacionais e culturais, sobre os quais não é possível discorrer no âmbito deste trabalho. A propósito, cf. CAMPILONGO, 2002; LOPES, 1989; MAUS, 2000.

Revista da Faculdade de Direito - UFPR, Curitiba, vol. 60, n. 1, jan./abr. 2015, p. 85-115.
} 
Nesse contexto, a competição ideológica, enquanto disputa entre diferentes projetos políticos e visões de mundo, e que é parte fundamental da política, ou é considerada como indesejável ou é controlada pelo poder econômico e pela mídia globalizada. Ou seja, a prática política depende da formulação de projetos alternativos e da mobilização de consensos em torno deles, mas os atores políticos perderam a capacidade de empreender tal tarefa, não são mais os protagonistas, de maneira que não lideram a sociedade, mas apenas seguem a onda do poder cultural hegemônico, o qual está vinculado ao poder econômico (DOGLIANI, 2000, p. 63-71).

Nessas condições, o individualismo passa a dominar a política, não são coletivamente construídos projetos sobre nosso futuro comum (BAUMAN, 2001, p. 124), a sociabilidade se manifesta exclusivamente em "explosões espetaculares, concentradas - e breves, como todas as explosões", por exemplo, em grandes atos de compaixão ou de agressão a alguém que "a maior parte do público identifica como um inimigo pessoal" (BAUMAN, 2000, p. 11), de maneira que não há estabilidade ou maiores compromissos nas atuais formas de agregação social.

Além disso, como destaca Giddens (2007, p. 82-4), com a revolução das comunicações, existe um conjunto maior de cidadãos bem informados e conscientes, os quais não se contentam com a política tradicional, pois a "política parlamentar ortodoxa fica distanciada da torrente de mudanças que passa impetuosamente pela vida das pessoas".

Assim, até se nota certa disposição das pessoas para desenvolver uma ação política não institucionalizada e hierarquizada, mas com um caráter individualista e difuso, valendose, sobretudo, das possibilidades geradas pelos novos meios de comunicação, como as redes sociais formadas pela internet. Essa forma de engajamento político, da qual se poderia esperar a compensação da tendência à despolitização da sociedade, na verdade tem "como motor a afirmação dos interesses particulares, não a construção de novos consensos, de novas 'sínteses políticas' ou de novas correlações políticas de forças” (NOGUEIRA, 2008, p. 16-7).

Evidencia-se, pois, que o enfrentamento do déficit democrático das instituições representativas exige tanto novos modelos institucionais capazes de permitir a formação e a expressão pacífica de dissensos nas esferas local, nacional, regional e global ${ }^{18}$, como também

\footnotetext{
${ }^{18}$ A teoria democrática tem desenvolvido importantes modelos que se apresentam como alternativas ao paradigma representativo tanto no plano descritivo-explicativo como no axiológico-prescritivo, a exemplo da "democracia deliberativa", do "pluralismo agonístico", da "democracia cosmopolita" e de "modelos não hierárquicos de democracia". Sobre esses modelos, cf., respectivamente, HABERMAS, 1997; MOUFFE, 2000, 2006; HELD, 1995, 2007; LADEURS, 2011. Este trabalho segue um plano analítico descritivo-explicativo, razão pela qual se limita a um diagnóstico sobre o déficit democrático das instituições representativas brasileiras Revista da Faculdade de Direito - UFPR, Curitiba, vol. 60, n. 1, jan./abr. 2015, p. 85-115.
} 
a formulação de alternativas políticas substanciais capazes de mobilizar os indivíduos em torno de projetos coletivos.

\subsection{DÉFICIT DEMOCRÁTICO DAS INSTITUIÇÕES REPRESENTATIVAS E A IMPOTÊNCIA DA POLÍTICA}

Já se destacou que o Estado, de modo geral, continua a desempenhar papéis relevantes, e que o brasileiro, em especial, nunca foi plenamente social nem republicano. Todavia, em virtude dos fatores já expostos, a globalização compromete decisivamente a capacidade estatal de tomar e concretizar decisões, atender às demandas da sociedade pela efetivação de direitos sociais e controlar uma série de variáveis com grande repercussão no interior de suas fronteiras. Há, portanto, a percepção de que se vive uma crise de impotência da política ${ }^{19}$ (DOWBOR, 2009, p. 618), pois questões fundamentais para a vida coletiva escapam da mediação das instituições representativas, questionando-se sua própria legitimidade. Assim, por mais democráticos que sejam os processos de formação de opinião e de decisão do povo e dos representantes, a incapacidade de executá-las gera um déficit democrático insanável.

Enquanto a economia se globalizou e muitos dos problemas a serem enfrentados são globais, a política continua essencialmente nacional. O emprego e, em grande medida, a qualidade de vida das pessoas, dependem da economia; todavia, os fatores econômicos determinantes não são controlados pelas instituições representativas, mas sim pelas forças do mercado global. Há, portanto, uma dissociação entre o poder de fato, aquele que determina os parâmetros da condição de vida das pessoas, e as instituições político-representativas: aquele é global (ou extraterritorial), fluido, ágil, enquanto essas se limitam ao espaço territorial do Estado nacional ${ }^{20}$. Falta, portanto, um agente político (que se submeta ao controle ou, pelo menos, à influência dos cidadãos) capaz de concretizar projetos democraticamente

decorrente da globalização. Em outro artigo, ainda inédito, mas vinculado ao mesmo projeto de pesquisa, e tomando-se como referência o diagnóstico aqui apresentado e os modelos teóricos citados, especialmente os dois últimos, desenvolveu-se uma abordagem de caráter propositivo, orientada para a formulação de propostas de inovação institucional que não se limitem ao paradigma democrático territorial-representativo, pois, embora permaneça importante, não é capaz de responder satisfatoriamente a todas as demandas por legitimidade e efetividade das instituições democráticas no contexto contemporâneo.

${ }^{19}$ Ortega y Gasset (2002, p. 42), no início do segundo quarto do século XX, descreveu um contexto semelhante: "vivimos en un tiempo que se siente fabulosamente capaz para realizar, pero no sabe qué realizar. Domina todas las cosas, pero no es dueño de sí mismo. Se siente perdido en su propia abundancia. Con más medios, más saber, más técnicas que nunca, resulta que el mundo actual va como el más desdichado que haya habido: puramente a la deriva. De aquí esa extraña dualidad de prepotencia e inseguridad que anda en el alma contemporánea".

${ }^{20}$ Cf. BECK, 1999, p. 27-8.

Revista da Faculdade de Direito - UFPR, Curitiba, vol. 60, n. 1, jan./abr. 2015, p. 85-115. 
formulados, inclusive determinando a forma como a riqueza é produzida e distribuída (BAUMAN, 2000, p. 27, 57-8, 172, 192; NOGUEIRA, 2008, p. 18).

O problema central do déficit democrático das instituições representativas resultante da globalização e do policentrismo do poder é, portanto, a "incapacidade cada vez mais acentuada do sistema político, ancorado no Estado-Nação, de representar os cidadãos na prática efetiva da governança global" (CASTELLS, 2005, p. 99).

Ora, as instituições da democracia liberal-representativa foram forjadas nos séculos XVIII e XIX para funcionar no âmbito do Estado nacional, a partir da concepção de que ele era o centro da política. A legitimidade dos governos para estabelecer o direito, regular a economia e mediar a vida social tinha como fundamento a manifestação das preferências individuais dos cidadãos nas eleições, segundo o princípio majoritário, e a garantia dos direitos fundamentais, tudo se passando no interior do território nacional. E assim, reconhecendo os limites e as contradições já expostos, a teoria política compreendeu a democracia até o final do século XX. Todavia, a partir do momento que é colocada em dúvida a centralidade política do Estado, especialmente em virtude de sua incapacidade de responder satisfatoriamente às demandas da sociedade, a compreensão da democracia e dos processos de legitimação restritos às instituições representativas estatais não é mais suficiente. Por exemplo, a manifestação do consenso eleitoral nacional em relação a questões como o meio ambiente global e o fluxo internacional de capitais é muito precária, pois o espaço decisório para temas como esses não é necessariamente o nacional, podendo ser o regional ou o internacional, da mesma maneira que a justificação das decisões por aqueles que recebem a atribuição de decidir, bem como sua prestação de contas e responsabilização, não pode ocorrer exclusivamente perante os cidadãos que vivem nos limites de determinado território nacional (HELD, 1995, p. 102).

A democracia, portanto, não pode continuar a ser pensada nos limites do Estado nacional, pois a política "mudou de lugar", desterritorializou-se (IANNI, 1997, p. 25). Isso não significa que se está diante do colapso da democracia e da política em si (NOGUEIRA, 2008 , p. 3-4, 7), pois continuam viáveis e indispensáveis - quem enfrenta uma crise de legitimidade e efetividade é a forma da política e da democracia vinculadas ao Estado nacional e às instituições representativas. É preciso, pois, pensar a política e a democracia considerando-se o Estado nacional, mas não se limitando a ele, e buscar formas institucionais que permitam a conciliação entre os foros em que as decisões são de fato tomadas e executadas e aqueles em que há participação democrática. Ou seja, na expressão de Giddens 
(2007, p. 84), "uma era globalizante exige respostas globais, e isso se aplica à política tanto quanto a qualquer outra área".

Com isso, não se está afirmando que toda a explicação e todas as soluções para os problemas políticos decorrentes da globalização se encontram no campo institucional. Porém, como assinala Castells (2005, p. 95-9), a crise das instituições políticas, neste contexto de transformações estruturais, constitui o "mais fundamental dos problemas que enfrentamos", pois, sem instrumentos suficientes e adequados de governança, não há como se pensar em resolver quaisquer dos outros problemas existentes. E se a governança não funciona, compromete-se a legitimidade das instituições representativas, cresce a distância entre "os cidadãos e seus representantes" e, no limite, coloca-se em risco a própria ideia democrática.

A nova institucionalização da política a ser desenvolvida precisa criar condições para "submeter a vida (os mercados, a economia, os interesses, os poderes) à regulação democrática", ou seja, para "o poder se reencontrar com a política, escapando dos circuitos globais capitalistas, dos bancos, das Bolsas de Valores e das grandes corporações". Por outro lado, deve permitir a participação da sociedade, por meio de mecanismos mais adequados aos anseios e à forma de organização da sociedade contemporânea, o que só será possível mediante a realização de reformas políticas que permitam a experimentação de diferentes modelos institucionais, "tornando-as mais coerentes, mais eficazes e mais dialógicas com a vida real do século XXI",21 (NOGUEIRA, 2008, p. 18-9).

Esse diagnóstico conduz a um amplo programa de pesquisa sobre a democracia no âmbito da Teoria do Estado, o qual consiste em verdadeiro exercício de engenharia institucional, ou seja: partindo-se das análises descritivo-explicativas da Ciência Política e dos novos modelos de democracia formulados pela Teoria Política, devem-se identificar alternativas democráticas emergentes e projetar reformas e construções de instituições jurídico-políticas adequadas ao contexto contemporâneo ${ }^{22}$.

\footnotetext{
${ }^{21}$ Giddens (2007, p. 29) assinala que "a impotência que experimentamos não é um sinal de deficiências individuais, mas reflete a incapacidade de nossas instituições. Precisamos reconstruir as que temos, ou criar novas. Pois a globalização não é um acidente em nossas vidas hoje. É uma mudança de nossas próprias circunstâncias de vida. É o modo como vivemos agora".

${ }^{22}$ Em trabalho ainda inédito, o autor desenvolve as bases epistemológicas deste programa de pesquisa, as quais constituirão o arcabouço teórico para o desenvolvimento de investigações futuras sobre a democracia no âmbito da Teoria do Estado.
} 


\section{CONCLUSÃO}

É preciso ter a clareza sobre o fato de que as instituições representativas brasileiras apresentavam um déficit democrático devido a causas anteriores e independentes do fenômeno da globalização (bloqueios à soberania, patrimonialismo, clientelismo, desigualdade social, etc.). Além disso, há limites, ameaças e paradoxos que acompanham a democracia representativa há muito tempo e também afetam a democracia brasileira. Assim sendo, observa-se que há um comprometimento da função representativa e do jogo democrático majoritário que não apresenta quaisquer relações com a globalização. Isso pode ser claramente ilustrado pelo avanço da atuação do Supremo Tribunal Federal em campos que sempre foram considerados próprios do Poder Legislativo, devido à inércia deste Poder no cumprimento de suas funções, o que tem suscitado reações de caráter corporativo e não propriamente no sentido de assumir sua missão institucional.

Isso não significa que o déficit democrático das instituições representativas brasileiras não tenha sido potencializado em virtude da globalização e do policentrismo do poder, bem como que não existam outras maneiras pelas quais se manifesta em virtude desses fenômenos. As consequências políticas da miséria, da exclusão e da desigualdade social, as crises de motivação, dos programas políticos e de impotência da política são condições que se aprofundaram. Além disso, se, no passado, era possível esperar que uma ação isolada do Estado fosse capaz de revertê-las, por meio da adoção de determinadas políticas sociais e econômicas, no contexto da globalização isso não é mais possível, de maneira que há uma demanda por uma ação política transterritorial. Há, portanto, um descompasso entre a economia que se globalizou e a política que permanece local, entre os espaços em que decisões importantes são de fato tomadas e executadas e aqueles em que há participação democrática, o que requer uma reconfiguração do projeto democrático a fim de que seja promovido o encontro entre essas duas instâncias, e o adequado enfrentamento da crise de impotência da política.

Portanto, não se pode pretender enfrentar o problema do déficit democrático das instituições representativas com os olhos voltados para um passado glorioso da democracia de base territorial, o qual, na verdade, nunca existiu, especialmente no caso brasileiro. Por outro lado, não há razões para um otimismo romântico sobre o futuro da democracia, o que fica evidenciado pelo contexto da atual crise econômica mundial e pela maneira como a União Europeia, experiência que inspira várias propostas de governança global e regional, tem reagido a ela. Além disso, se, na Europa, a globalização foi decisiva para um processo de 
desmonte do Estado Social, o qual vem sendo agravado pela atual crise econômica, no Brasil, a ausência do Estado perante as questões sociais é histórica, assistindo-se, ao contrário, na última década, um crescimento de sua intervenção nos campos econômico e social.

É a partir desse diagnóstico radical, realista e desconfortante que devem ser buscadas inovações institucionais capazes de responder aos novos desafios para a democracia no Brasil e na América Latina.

\section{REFERÊNCIAS}

AMARAL JÚNIOR, Alberto. Introdução do direito internacional público. São Paulo: Atlas, 2008.

ARENDT, Hannah. Origens do totalitarismo. Tradução de Roberto Raposo. São Paulo: Companhia das Letras, 1989.

ARCHIBUGI, Daniele. Demos and Cosmopolis. New Left Review, London, v. 42, n. 13, p. 24-38, jan./fev.

2002.

Disponível

em:

$<$ http://www.danielearchibugi.org/downloads/papers/Archibugi_Demos_and_Cosmopolis_N LR_13.pdf>. Acesso em: 15 out. 2012.

. Notes on Democracy in the European Union. The European Union Review, v. 10, n. 1, p. 75-86, 2005. Disponível em: $<$ http://www.danielearchibugi.org/downloads/papers/Notes_on_Democracy_in_the_European _Union.pdf $>$. Acesso em: 15 out. 2012.

BAUMAN, Zygmunt. Em busca da política. Tradução de Marcus Penchel. Rio de Janeiro: Zahar, 2000.

. Modernidade líquida. Tradução de Plínio Dentzien. Rio de Janeiro: Zahar, 2001.

BECK, Ulrich. O que é globalização? Equívocos do globalismo: respostas à globalização. Tradução de André Carone. São Paulo: Paz e Terra, 1999.

BENEVIDES, Maria Victoria de Mesquita. Em defesa da república e da democracia. In: BENEVIDES, Maria Victoria de Mesquita; BERCOVICI, Gilberto e MELO, Claudineu (Org.). Direitos humanos, democracia e república - Homenagem a Fábio Konder Comparato. São Paulo: Quartier Latin, 2009. p. 723-38.

BOBBIO, Norberto. Direita e esquerda: razões e significados de uma distinção política. Tradução de Marco Aurélio Nogueira. 2. ed. São Paulo: UNESP, 2001.

. Teoria geral da política: a filosofia política e as lições dos clássicos. Tradução de Daniela Beccaccia Versiani. Rio de Janeiro: Campus, 2000.

Qual socialismo? Debate sobre uma alternativa. Tradução de Iza de Salles Freaza. Rio de Janeiro: Paz e Terra, 1983. 
. O Futuro da democracia. Tradução de Marco Aurélio Nogueira. 10. ed. Rio de Janeiro: Paz e Terra, 2006.

; VIROLI, Maurizio. Diálogo em torno da república: os grandes temas da política e da cidadania. Rio de Janeiro: Campus, 2002.

BONAVIDES, Paulo. A constituição aberta. $3^{\text {a }}$ ed. São Paulo: Malheiros, 2004.

CAMPILONGO, Celso Fernandes. Direito e democracia. 2a . ed. São Paulo: Max Limonad, 2000.

Política, sistema jurídico e decisão judicial. São Paulo: Max Limonad, 2002.

CASSESSE, Sabino. L'Erosione Dello Stato: una Vicenda Irreversibile? In: CASSESE, Sabino. Dallo Stato Monoclasse alla Globalizzazione. Milano: Giuffrè, 2000. p. 15-23.

CASTELLS, Manuel. A crise da democracia, governança global e a emergência de uma sociedade civil global. In: Por uma governança global democrática. São Paulo: Instituto Fernando Henrique Cardoso, 2005. p. 95-128.

. A Sociedade em rede. Tradução de Roneide Venancio Majer e Klauss Brandini Gerhardt. São Paulo: Paz e Terra, 2009.

COMPARATO, Fábio Konder. Ética: direito, moral e religião no mundo moderno. São Paulo: Companhia das Letras, 2006.

COSTA, José Augusto Fontoura. Globalização e fim do estado. In: DERANI, Cristiane; COSTA, José Augusto Fontoura. Globalização \& soberania. Curitiba: Juruá, 2004. p. 33-60.

DOGLIANI, Mario. Deve la Politica Democratica Avere una sua Risorsa di Potere Separata? In: CASSESE, Sabino. Dallo Stato Monoclasse alla Globalizzazione. Milano: Giuffrè, 2000. p. 61-72.

DOWBOR, Ladislau. A crise financeira sem mistérios. Convergência dos dramas econômicos, sociais e ambientais. São Paulo: 2009. Disponível em: $<$ http://dowbor.org/crisesemmisterios8.pdf>. Acesso em: 19 abr. 2011.

. Tecnologia, globalização e governabilidade. In: DOWBOR, Ladislau. A reprodução social. São Paulo, 2001. Disponível em: < http://dowbor.org/2003/05/tecnologiaglobalizacao-e-governabilidade.html/>. Acesso em: 19 abr. 2011.

FAORO, Raymundo. Os donos do poder: formação do patronato político brasileiro. v. 2. 6 . $^{\text {a }}$ ed. Porto Alegre: Globo, 1979.

FARIA, José Eduardo. A nova pauta das escolas de governo: policentrismo decisório e lluralismo jurídico. Disponível em: <http://www.fundap.sp.gov.br/../Apresentação\%20\%20José\%20Eduardo\%20Faria\%2009_06.pdf - Similares>. Acesso em: 27 abr. 2011. 
. Democracia e governabilidade: os direitos humanos à luz da globalização econômica. In: FARIA, José Eduardo. Direito e globalização econômica: implicações e perspectivas. $1^{\text {a }}$ ed. São Paulo: Malheiros, 2010. p. 127-60.

. Estado, sociedade e direito. In: FARIA, José Eduardo; Kuntz, Rolf Nelson. Qual o futuro dos direitos? Estado, mercado e justiça na reestruturação capitalista. São Paulo: Max Limonad, 2002. p. 59-123.

. O Direito na economia globalizada. São Paulo: Malheiros, 2002.

. Sociologia jurídica - direito e conjuntura. São Paulo: Saraiva, 2008.

FERRAJOLI, Luigi. A soberania no mundo moderno - Nascimento e crise do estado nacional. Tradução de Carlo Coccioli e Márcio Lauria Filho. São Paulo: Martins Fontes, 2007.

O Estado de direito entre o passado e o presente. In: COSTA, Pietro; ZOLO, Danilo. O Estado de direito: história, teoria, crítica. Tradução de Carlo Alberto Dastoli. São Paulo: Martins Fontes, 2006. p. 447-64.

GIDDENS, Anthony. Mundo em descontrole. Tradução de Maria Luiza X. de A. Borges. $6^{\mathrm{a}}$ ed. Rio de Janeiro: Record, 2007.

HABERMAS, Jürgen. A constelação pós-nacional: ensaios políticos. Tradução de Márcio Selegmann-Silva. São Paulo: Littera Mundi, 2001.

. Direito e democracia - entre facticidade e validade. Tradução de Flávio Beno Siebeneichler. Rio de Janeiro: Tempo Brasileiro, 1997.

HELD, David. Cosmopolitanism: Ideas, Realities and Deficits. In: HELD, David; MCGREW, Anthony. Governing Globalization - Power, Authority and Global Governance. Cambridge, UK: Polity, 2007, p. 305-324.

. Models of Democracy. $3^{\mathrm{a}}$ ed. Stanford: Stanford University, 2006.

. Democracy and the New International Order. In: HELD, David; ARCHIBUGI, Daniele. Cosmopolitan Democracy: an Agenda for a New World Order. Oxford, UK: Polity, 1995. p. 96-120.

; MCGREW, Anthony. Introduction. In: HELD, David; MCGREW, Anthony. Governing Globalization - Power, Authority and Global Governance. Cambridge, UK: Polity, 2007. p. 1-19.

HÖFFE, Otfried. A democracia no mundo de hoje. Tradução de Tito Lívio Cruz Romão. São Paulo: Martins Fontes, 2005.

HOLANDA, Sérgio Buarque de. O homem cordial. In: Raizes do Brasil. $6^{\text {a }}$ ed. Rio de Janeiro: José Olympio, 1971, p. 101-12. 
IANNI, Octávio. A política mudou de lugar. In: DOWBOR, Ladislau; IANNI, Octávio; RESENDE, Paulo-Edgar. Desafios da globalização. Petrópolis: Vozes, 1997. p. 17-27.

. Teorias da globalização. $8^{\mathrm{a}}$ ed. Rio de Janeiro: Civilização Brasileira, 2000.

KNOERR, Fernando Gustavo. Representação política e globalização. In: FONSECA, Ricardo Marcelo. Repensando a teoria do estado. Belo Horizonte: Fórum, 2004. p. 175-180.

LAMONIER, Bolívar. Tendências anti-institucionais no Brasil pós-transição: populistas, "picaretas" e carbonários. In FAUSTO, Sérgio (Org.). Difícil democracia. São Paulo: Paz e Terra, 2010. p. 81-103. p. Disponível em: $<$ http://www.plataformademocratica.org/Publicacoes/17335.pdf $>$. Acesso em: 15 out. 2012.

LADEURS, Karl-Heinz. Globalisation and the Conversion of Democracy to Polycentric Networks: Can Democracy Survive the End of the Nation State? San Domenico: European University Institute, 2003. Disponível em: $<$ http://cadmus.eui.eu/bitstream/handle/1814/199/law03-4.pdf? sequence=1>. Acesso em 3 nov. 2011.

LEWANDOWSKI, Enrique Ricardo. Globalização, regionalização e soberania. São Paulo: Juarez de Oliveira, 2004.

LOPES, José Reinaldo de Lima. A função política do Poder Judiciário. In: FARIA, José Eduardo (Org.), Direito e justiça - A função social do Judiciário. São Paulo: Ática, 1989. p. 123-44.

MAUS, Ingborg. Judiciário como superego da sociedade-O papel da atividade jurisprudencial na "sociedade órfă”. Novos Estudos, n. 58, nov. 2000.

MOUFFE, Chantal. On the Political. London: Routledge, 2006.

. The Democratic Paradox. London: Verso, 2000.

MULLER, Friedrich. Democracia e exclusão social em face da globalização. Revista Jurídica

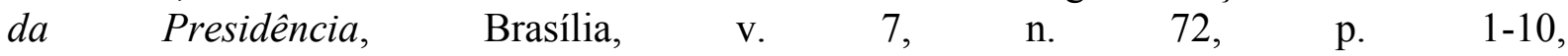
maio $2005 . \quad$ Disponível em: $<$ http://www.planalto.gov.br/ccivil_03/revista/Rev_72/artigos/PDF/Friedrich_Rev72.pdf $>$. Acesso em: 24 fev. 2012.

NANZ, Patrizia, STEFFEK, Jens. Global Governance, Participation and Public Sphere. In: HELD, David; MATHAIS, Koenig-Archibugi. Global Governance and Public Accountability. Malden: Mass Blackwell, 2007. p. 190-211.

NEVES, Marcelo da Costa Pinto. Entre Têmis e Leviatã: uma relação difícil-o estado democrático de direito a partir e além de Luhmann e Habermas. 2. ${ }^{a}$ ed. São Paulo: Martins Fontes, 2008.

NOBRE, Marcos. O condomínio peemedebista - as polarizações artificiais que travam o debate público. Folha de São Paulo, São Paulo, 15 maio 2011. Ilustríssima, p. I, 4-5. 
NOGUEIRA, Marco Aurélio. Da frustração à reposição da confiança na política. São Paulo, 2008.

Disponível

em:

$<$ http://www.fundap.sp.gov.br/DEBATESFUNDAP/PDF/QUINTO_SEMINARIO/EXPOSI\% C3\%A7\%C3\%A3O_DO_PROFESSOR_MARCO_AUR\%C3\%A9LIO_NOGUEIRA.PDF $>$.

Acesso em: 16 mai. 2011.

Um estado para a sociedade civil. São Paulo: Cortez, 2004. p. 77-116.

ORTEGA Y GASSET, José. La Rebelión de las Massas. Madrid: El País, 2002.

SANTOS, Boaventura de Souza. Reinventar a democracia: entre o pré-contratualismo e o pós-contratualismo. In: OLIVEIRA, Francisco; PAOLI, Maria Célia (Org.). Os sentidos da democracia - políticas do dissenso e hegemonia global. $2^{\mathrm{a}}$ ed. Petrópolis: Vozes; Brasília: NEDIC, 1999. p. 83-129.

SARTORI, Giovanni. Homo videns - televisão e pós-pensamento. Bauru: EDUSC, 2001.

SCHWARTZENBERG, Roger-Gérard. O estado espetáculo: ensaio sobre e contra o star system em política. Tradução de Heloysa de Lima Dantas. Rio de Janeiro: Difel, 1978.

STUCHI, Carolina Gabas. A inadequação entre idéia e realidade na periferia: os limites da teoria geral do estado para a compreensão do estado brasileiro. 2007. 269 p. Tese (Doutorado em Direito do Estado) - Faculdade de Direito da Universidade de São Paulo, São Paulo, 2007.

VILLA, Marco Antonio. Fracassamos. Folha de São Paulo, São Paulo, 29 mar. 2012. Primeiro Caderno, p. A 3, Opinião.

ZOLO, Danilo. Teoria e crítica do estado de direito. In: COSTA, Pietro; ZOLO, Danilo. $O$ estado de direito: história, teoria, crítica. Tradução de Carlo Alberto Dastoli. São Paulo: Martins Fontes, 2006. p. 62-84.

\section{GLOBALIZATION AND THE DEMOCRATIC DEFICIT OF BRAZILIAN REPRESENTATIVE INSTITUTIONS}

ABSTRACT: Due to globalization, the state lost its monopoly on political mediation. For example, it began to share decisions with multiple stakeholders, internal and external, and is not able to control several variables that interfere in national life. This has impacts on the functioning and legitimacy of representative institutions. However, there are paradoxes that accompany them since their beginnings, and semi-peripheral states, like Brazil and other Latin Americans, have some historical-cultural issues such as internal and external sovereignty locks, patrimonial, clientelist, and populist political culture and a society precariously integrated, with deep inequalities, which also explain the problems of democracy. Thus, the purpose of this research was to investigate which characteristic features of the democratic deficit of the Brazilian representative institutions were in fact caused or exacerbated by globalization. Thus, we sought to overcome simplistic analyzes, which attribute all the problems of contemporary democracy to globalization, or else insist on restricting the field of analysis of the limits established by the representative democratic model of territorial base, which presents potential explanatory limited in a context of political 
polycentrism, and in that the representative institutions reveal themselves incompatible with the demands of social mediation.

KEYWORDS: Globalization. Political polycentrism. Representative democracy.

Recebido: 4 de agosto de 2014

Aprovado: 17 de outubro de 2014 